\title{
Collective Responses to the Economic Crisis in the Public Domain:
}

\author{
Myth or Reality?
}

\author{
MANLIO CINALLI \\ CEVIPOF, Sciences Po Paris, \\ MARCO GIUGNI \\ University of Geneva
}

We challenge the common wisdom that the Great Recession has produced radical changes in political behavior. Accordingly, we assess the extent to which the crisis has spurred protest activities and given socioeconomic issues a higher saliency in public debates. We also assess how far the crisis has provided a more prominent place for economic and labor actors as subject actors, a more prominent place of economic and labor actors as object-actors, as well as a more prominent place of economic and labor actors as addressees in claims-making on the economic crisis. Our findings show that the crisis has not produced such radical changes in all these aspects, although it had some impact. At a more general level, our analysis unveils the normative underpinnings of the commonly held view that the economic crisis has fed a grievance-based conflict between capital and labor going beyond specific patterns and configurations in each country.

Keywords: Political Behavior, Economic Crisis, Europe, Great Recession, Public Domain, Public Debates, Protests, Claims-making, Political Opportunity Structures, National Politics, Economic Organizations, Labor Organizations, Policy Domain, Normative Bias, Demystifying the Economic Crisis, Special Issue on the Economic Crisis.

Related Articles in this Special Issue: Zamponi, Lorenzo, and Lorenzo Bosi. 2016. "Which Crisis? European Crisis and National Contexts in Public Discourse." Politics \& Policy 44(3). INSERT WEBADDRESS HERE WHEN AVAILABLE.

Marco Giugni, and Maria T. Grasso. 2016. "How Civil Society Actors Responded to the Economic Crisis: The Interaction of Material Deprivation and Perceptions of Political Opportunity Structures." Politics \& Policy 44(3). INSERT WEBADDRESS HERE WHEN AVAILABLE.

Theiss, Maria, Anna Kurowska, and Janina Petelczyc. 2016. "Whose Rights, Which Duties? Political Claims in the Sphere of Labour Policy in the Times of Crisis - The Social Citizenship Perspective." Politics \& Policy 44(3). INSERT WEBADDRESS HERE WHEN AVAILABLE.

We would like to thank Eva Anduiza and Luke Temple for their detailed and thoughtful comments on a previous version of this article. All remaining errors are, of course, our own and we take full responsibility. Please send all correspondence to Marco Giugni, Département de science politique, Université de Genève, Uni-Mail, 1211 Genève 4, Switzerland marco.giugni@unige.ch. Results presented in this article have been obtained within the project "Living with Hard Times: How Citizens React to Economic Crises and Their Social and Political Consequences" (LIVEWHAT). This project was funded by the European Commission under the $7^{\text {th }}$ Framework Programme (grant agreement no. 613237). 
Related Media: Prof. Colin Crouch. 2015. "Inequality \& Post-Democracy." https://www.youtube.com/watch?v=QNkKsMXXjXU

Talk Real. 2015, "Voices: Gerardo Pisarello (Barcelona vice Mayor) with Daphne Buellesbach." https://www.youtube.com/watch?v=y0sC7iR-OsI

Desafiamos la concepción general que la Gran Recesión ha generado cambios radicales en la conducta política. Por lo tanto, analizamos el grado en el que la crisis ha provocado manifestaciones y dado mayor prioridad a los problemas socioeconómicos en los debates públicos. De igual manera, analizamos en qué medida la crisis económica ha dado mayor prominencia a los actores económicos y laborales como actores sujeto-objeto, así como una mayor prominencia a estos actores como recipientes de declaraciones políticas en la crisis económica. Nuestros resultados sugieren que la crisis no ha provocado cambios radicales en estos aspectos, aunque si ha tenido un impacto. A un nivel más general, nuestro análisis revela los principios normativos de la concepción que sostiene que la crisis económica ha alimentado el conflicto entre el trabajo y el capital sin tomar en cuenta los patrones $y$ configuración especifica de cada país. 
A lot has been said and written about the impact of the Great Recession on European society and politics. The most common storyline striking the attention of scholars of political behavior is that the crisis has brought about a huge rise of anti-austerity protest movements (Ancelovici, Dufour, and Nez 2016; della Porta 2014; della Porta and Mattoni 2014; Gamson and Sifry 2013; Pickerill and Krinsky 2012). In this article we are interested in assessing the political effects of the crisis on the political mobilization of Europeans, looking more specifically at the effects on how main organized actors intervene in the public domain. Concerning the collective responses to the crisis in the public domain, according to the common storyline one would expect some endemic spreading of contentious politics, with a steep growth of protest as opposed to other forms of intervention and a higher salience of socioeconomic issues.

This study challenges the common wisdom that the Great Recession has produced radical changes in terms of political behavior and more specifically in terms of a rise in protest actions. In arguing that a strong competitive bias has been placed at the core of main normative understandings of democracy, we expect that the common storyline about the dramatic impact of the economic crisis in fact overstates its real impact, at least as far as contentious dynamics are concerned. We thus unveil the normative bias that dramatizes the conflict between contrasting interests at stakes during the crisis, thereby "demystifying" the idea that major changes have been produced in the ways issues are debated in the public domain, in the place of different actors, and the ways these latter intervene.

Our analysis proposes an alternative account that retrieves the importance of national politics in terms of structures, actors, and strategic interventions. Inspired by the literature on the role of national political opportunity structures for the mobilization of social movements, we examine the extent to which the Great Recession has impacted on the political claims making of collective actors in different countries. In particular, we pay special attention on 
economic actors (such as banks and financial/investment institutions, credit rating agencies, private companies, and employers' organizations) and labor actors (such as unions, workers and employees, and other work-related organizations). These two types of organized actors arguably have the most contrasting interests and stakes on the socioeconomic dimension of the political space, but especially so in periods characterized by economic recession and financial hardship. It is in such difficult times that policy making must be shaped in a way to counter the negative effects of the crisis. In this context of high competition among contrasting interests, economic and labor actors will likely clash with policy makers and among each other. Accordingly, we assess the extent to which the crisis has not only spurred protest activities and given socioeconomic issues a higher saliency in public debates, but also provided a more prominent place for economic and labor actors as subject actors, a more prominent place of economic and labor actors as object-actors, as well as a more prominent place of economic and labor actors as addressees in claims-making around issues pertaining to the economic crisis. To do so, we examine whether and how claims-making over the economic crisis has changed over time, as the crisis unfolded and reached its peak, and across countries, as not all countries were equally affected by the crisis. We do so through the analysis of press coverage of political claims made by collective actors in nine European countries: France, Germany, Greece, Italy, Poland, Spain, Sweden, Switzerland, and the UK.

\section{National Political Opportunity Structures and Claims-Making over the Economic Crisis}

Since 2008, the dramatic impact of the Great Recession has been discussed extensively in public and political debates. The most common storyline is that the crisis has deep - and perhaps longstanding - economic effects which can be felt at different levels beyond economics: socially first of all, through an increase of precarity in the labor market, a weakening of the position of the middle class, the strengthening of inter-generational conflict and the loosening of social bonding in general (Fraser 2015; Palier 2014; Stiglitz 2015); but 
also politically, through the increasing clash between the winners and the losers of the crisis, the emergence of new populist parties, the failure of citizenship regimes of integration and, most importantly for this article, the rise of anti-austerity protest movements (Bermeo and Bartels 2014; Giugni and Grasso 2015; Kriesi and Pappas 2015).

This article aims to assess the political effects of the Great Recession on claimsmaking over the economic crisis and, more specifically, its effects on the role of economic and labor organizations therein. Do we observe an increase in protests since the start of the crisis, as many scholars and pundits have argued? Are socioeconomic issues more visible owing to their centrality for economic and labor organizations? How did these actors address the crisis in the public domain? Have economic and labor actors become more central in public debates at some stage and in some country in particular?

The fact that legal norms, institutional structures and practices, as well as discourse, vary from country to country is a key element in our comparative approach. On the one hand, our alternative account is inspired by the political process approach to social movements and, more specifically, by political opportunity theory (see, for reviews, Kriesi 2004; Meyer 2004). According to this theory, the specific national configurations of political institutions and alignments go a long way in explaining the rise and decline of social movements as well as the forms the take. In other words, this approach stresses the impact of national traditions and structures. Yet it should be emphasized that we engage with political claims making more generally and not only with social movements and protest activities (Giugni 2010; Koopmans et al. 2005). Political opportunity theory has stressed the role of the broader institutional context for the emergence, mobilization, and outcomes of social movements. Cross-national studies have shown how the level and forms, but also the effects of movements are strongly contingent upon the existence of favorable-often the term "open" is used-political opportunity structures (Kitschelt 1986; Kriesi et al. 1995). Furthermore, the opening up of 
"windows of opportunities" has been shown to be critical to explaining the ebbs and flows of protest over time (Tarrow 1989, 2011).

On the other hand, a number of scholars have introduced the idea that political opportunities also have a more informal, symbolic, and discursive side, in addition to their formal and institutional side. Works in the field of migration and ethnic relation politics, in particular, have stressed how citizenship models may affect the mobilization of migrants and more generally claims making in this field not only through their formal side, but also and perhaps above all thanks to their discursive side (Cinalli and Giugni 2013b, 2011; Giugni and Passy 2004; Koopmans and Statham 1999; Koopmans et al. 2005). As such, they provide different degrees of visibility, resonance, and legitimacy to certain actors and issues in the public domain, which in turn opens up or closed down opportunities for mobilization by migrants, or other claimants in other fields. ${ }^{1}$

Here we follow up on this line of reasoning by considering how national public discourses may have their own logic that make a homogeneous impact of the economic crisis quite unlikely. In other words, in addition to the constraining and channeling role of national institutional structures, specific national "discursive structures" should also go against the expectations of the standard storyline about the impact of the economic crisis on political claims making. Hence, the study of the political, legal, and administrative contexts of opportunity structures goes side by side with the study of discursive constructions that actors contribute to shape through their interventions in the public domain. These discursive interventions play a crucial role in our research since their analysis can also be useful to seize the broader importance of communicative tools of expressions passing through symbols, narratives, rhetoric, and so forth. Therefore, according to our account, the public domain is shaped according to specific settings in each country, and what we observe since the crisis

\footnotetext{
${ }^{1}$ See Giugni (2010) for claims making in the unemployment field.
} 
may very much be influenced by the variation of these cross-national settings. In stronger terms, we expect that the crisis, which certainly had a number of social and political consequences such as for example the rise of populist parties or their strengthening, did not have a direct effect on the structuring of public debates, even when dealing with most conflictual interests by, and over, economic and labor organizations, respectively.

Behind our specific interest in "demystifying" the most common account of the impact of the Great Recession on political claims making lies a more general issue with which we would like to engage. We refer to a number of potential misunderstandings that are grounded on a far too competitive conception of politics. Paradoxically, this competitive conception is shared across a wide spectrum of normative accounts, linking the neo-liberal perspective on the one pole to the neo-Marxist perspective on the other (Engelmann 2003; Gagnier 1997; Jaret 1983; Therborn 1986; Touraine 1971). Grounded across both poles, one finds the traditional idea that that conflict is an inherent characteristic of humans. View from this perspective, the homo economicus has not evolved that much from its original wolf nature, since he is still sufficiently unsophisticated to put his particular interest (whether individual or class-based) before "the force of better argument" to the advantage of all (Habermas 1984). This normative bias is based on a conflictual dogma that in fact prevents any view on alternative dynamics in the political domain whereby actors prefer to listen carefully and to be responsive to what other actors have to say so as to agree on decisions that may be better for all and hence produce a number of normatively desirable consequences (Delli Carpini, Lomax Cook, and Jacobs 2004; Fishkin 1995; Mendelberg 2002; Searing et al. 2007). An additional risk is that this conflictual dogma does not only remain just at the basis of a general notion of politics, but spills over an unlimited number of specific political fields that are only considered for their conflictual dynamics. To name just a few most recent examples: the refugee crisis has reinforced the idea that migrants' claims are necessarily in opposition to 
citizens' rights; the malfunctioning of the labor market have encouraged the cutting of workers' rights since these latter are allegedly in conflict with the rights of the unemployed; the defense of industrial facilities (and their employees) is resisted by those who put first the protection of the environment. This understanding of politics as a permanent conflict has spread as far as permeating the relationship between parents and their children-characterized by inter-generational scars and warfare (Binney and Estes 1988; Clark, Georgellis, and Sanfey 2001; Heckmann and Borjas 1981) — as well as the demise of welfare in the conflict between beneficiaries on the one hand and decision makers on the other (Castles 2004; Cinalli and Giugni 2013a; Esping-Andersen 1996; Hubert 2010; Kuhnle 2000).

Scholars of contentious politics have no doubt embraced such a conflictual bias of politics. Since their seminal steps (Eisinger 1973; McAdam 1986; Tarrow 1989; Tilly 1978), they have chosen to focus on most conflictual moments throughout history by putting the opposition between challengers and insiders at the core of their accounts of social movements and political behavior. This focus on a challengers/insiders cleavage has served quite well the purpose of building up high levels of sophistication in the analysis of collective mobilization, leading to the most accomplished elaborations in the field (Kriesi et al. 1995; Tilly and Tarrow 2007). Yet some scholars have grown unsatisfied with this heuristic and have approached differently social movements and collective mobilizations (Cinalli 2003, 2004; Cinalli and Fuglister 2008; Diani 1992, 1995; Diani and McAdam 2003; Fillieule 2005; Hayes 2005). In line with these crucial developments, our effort to unveil the true extent of conflict around the interests of capital and labor respectively at the time of the Great Recession should be seen as an attempt to deal with new challenges facing contemporary examinations of contentious politics, and democracy more generally. Simply put, our analysis aims to offer a more realistic representation of diachronic and cross-national variations of political contention, as it has given substance to the greatest crisis Europe has seen since 
WWII. In particular, our diachronic consideration of nine European countries allows for appraising whether their large variations in institutional, policy, and discursive approaches identify some clear patterns in terms of the claims making of, and over, economic and labor organizations.

To sum up, a major added value of this study, we hope, consists in challenging common accounts of the impact of the Great Recession on public debates in Europe based on a political opportunity approach, while opening a broader reflection about the role of capital and labor in times of economic crisis. Empirically, this translates into a diachronic comparison of economic actors and labor actors in nine European countries. As representatives of capital and labor respectively, these two types of collective actors arguably have different interests and stakes in general, but especially so in periods characterized by economic recession and financial hardship. It is in such difficult times that decision makers must adopt policies aimed at countering the negative effects of the crisis, and this is where economic and labor actors are expected to disagree. During the Great Recession policies have been the same virtually everywhere in Europe: strong cuts in government spendingespecially in the social sector-accompanied by an increase in taxation. In short, European governments have responded to the crisis through austerity policies. Whatever the account of competitive politics being taken as a normative guide, economic and labor actors are expected to have a different stance towards such measures.

\section{Data and Methods}

The data used in this article comes from a systematic content analysis of newspapers in each of the countries under study. Following the methods of political claims making analysis (Koopmans and Statham 1999) which has proved fruitful in previous work on social movements and contentious politics, we have created a comparative dataset by random sampling about 1000 claims per country (for a total sample of 9033 claims) selected from five 
newspapers in each country and covering the period from 2005 to 2014 (in Greece and Poland the number of newspapers have been reduced for practical reasons). The choice of newspapers has followed from the need to insure as much as possible a representative and unbiased sample. Therefore, we have included both "quality" broadsheet newspapers and more tabloidoriented newspapers. Furthermore, we have considered newspapers from different political orientations as well as more "neutral" newspapers. All articles containing any of the three words "crisis," "recession, or "austerity" have been selected and coded, to the extent that they referred to the current economic crisis. The articles have been sampled from all newspaper sections, excluding editorials, through key words search. In this paper we only use the claims that occurred between 2008 and 2014. The year 2008 can be considered as the start of the economic crisis in Europe, although the true beginning varies from one country to the other and the financial crisis took place one year earlier.

We show support to our argument in a simple way, by means of analysis in the form of frequencies and cross-tabulations. We show two types of tables: by year and by country. The former is meant to address the commonly held hypothesis that the crisis matters on a number of aspects relating to public interventions about the economic crisis (if the hypothesis is true, we should observe strong variations over time in those aspects since the start of the crisis); the latter aims to show that what matters are in fact national traditions and political opportunity structures (if our argument is correct, we should observe strong cross-national variations that are independent from the crisis). We examine in particular five main aspects of claims: the share of protest events over all claims bearing on issues pertaining to the economic crisis; the share of socioeconomic issues, as opposed to other issues; the share of labor and economic organizations as subject actors, as opposed to other subject actors; the share of labor and economic organizations as object actors, as opposed to other actors; the share of labor and economic organizations as addressees, as opposed to other actors. We look at all these aspects 
both over time and across nine countries: France, Germany, Greece, Italy, Poland, Spain, Sweden, Switzerland, and the UK.

\section{Findings}

Our analysis proceeds in two steps: in a first step, we look at changes over time in the five aspects of claims mentioned earlier; then, in a second step, we look at how these aspects vary across countries. The first step provides us with a general overview of how public debates about the crisis have unfolded during the Great Recession, whereas the second step allows us to tackle more directly the role of national contexts and traditions. For both types of analysis, we show the coefficients of associations (Cramer's V) as well as their significance level.

Table 1 shows the changes over time, from 2008 to 2014. To start with, let us look at the share of protest actions (first row), which is the most relevant aspect in a political opportunity perspective. Pundits and scholars alike have often stressed the fact that the economic crisis has spurred a wealth of protest across Europe, especially in those countries most severely affected by its negative consequences. In the social movement literature, this view is often associated with grievance-based theories of collective behavior (see Buechler 2004). Overall, however, our data suggest that this is at best only partly true. First, the overall level of protest is quite limited, never exceeding 8 percent of all claims. This rejoins Bermeo and Bartels' (2014) argument that we tend to overstate the amount of protest spurred by the crisis because certain major events, such as the large Indignados demonstrations in the Summer of 2011 or Occupy Wall Street in the Fall of the same year, have made the front page of the news, giving the idea of a much larger protest wave than it actually was. Thus, different types of actors have reacted to the crisis more often through other means, namely by means of verbal claims. Second, while from 2008 to 2012 the share of protest actions over all claims bearing on issues pertaining to the crisis went up, producing a sort of inverse u-shaped 
distribution with the subsequent decline, the increase is relatively limited. As for most of the aspects examined here, differences from one year to the other are statistically significant, but the low Cramer's V suggests a weak relationship between the share of protests and the year.

\section{Table 1 about here}

Others have argued that it is not so much the extent of the crisis and the grievances it produced that has led to mass protest, but rather the austerity measures implemented in most European country (Bermeo and Bartels 2014). This seems a more plausible view as the highest share of protests occurred in 2011 and 2012, which is when austerity policies were fully implemented throughout the whole Europe. Again, however, the evidence suggests that such an impact is at best a moderate one.

Moving to the content of claims (second row), we can see that, overall, more than half of all claims deal with socioeconomic issues. In other words, during the crisis, and especially so at its peak in 2011, attention was directed to issues pertaining to macroeconomics, labor and employment, social policy, and economic activities and domestic commerce. Of these, the lion's share is taken by macroeconomic issues (about half of all claims). While we cannot see the thematic focus of claims before the crisis as well as beyond the general reference to it, we observe a relative stability during the period under study, that is, during the crisis itself. Yet, just as for protest actions, we also observe a slight increase from 2008 to 2011, followed by an equally slight decline afterwards. Again, the findings data are far from being conclusive in one direction or the other.

The next six analyses all deal with the two more specific actors we would like to zoom in on: economic and labor organizations respectively. The first two analyses consider them as subject actors, that is, as makers of claims (third and fourth rows). As we said earlier, one may expect these two actors to have played an increasingly important role in public debates during the economic crisis as they are most directly concerned by it, although for different reasons. 
Concerning the former, our data show exactly the opposite: a steady decline over time in the share of economic organizations as subject actors. Their overall presence is high (about 27 percent of all claims), but it is much higher in 2008 than in 2014. Thus this type of actor becomes less rather than more visible during the crisis. As for labor actors, we observe a rather stable distribution over time. They become a little more present in 2009 and 2010, but then their presence goes down again. Moreover, their role in claims making is much less prominent that that of economic actors. ${ }^{2}$

These patterns are quite similar to those observed when we look at economic and labor organizations as object actors (fifth and sixth row), that is, when they are the actors "at stake" in claims making rather than the active protagonists of claims. Here too, economic actors are much more prominent than labor actors (34 percent, respectively; 13 percent of all claims). Most importantly, the share of economic organizations as object actors displays a steady decline from 2008 to 2014 , with a particularly pronounced fall in 2009 , when the crisis was starting to make their negative effects visible to everybody. Also, similarly to what we observed for subject actors, the share of labor organizations as object actors is quite stable over time. Perhaps the only single exception is an important increase in 2009, suggesting that, precisely when the crisis started to become visible to all, labor actors were often mentioned as objects of claims.

Finally, we can also look at economic and labor organizations as addressees (seventh and eighth row), that is, when standing out in their quality of actors to whom a claim is explicitly addressed, and more broadly speaking, the actors whom the claim makers refer to. Once again, overall economic actors are more often mentioned as addressees than labor actors, although both at a much lower level than when they are mentioned as subject actors or

\footnotetext{
${ }^{2}$ If we look at protest actions only, however, labor actors are more present (38 percent, respectively; 10 percent of all claims) owing to the mobilization role played by unions and the labor movement more generally.
} 
as object actors. ${ }^{3}$ The diachronic trend for both actors is also in line with previous observations (even if less pronounced), that is, a declining trend for economic organizations and a relatively stable trend stability for labor organizations.

Table 2 shifts the analysis to cross-national comparisons and shows, for all the same aspects, whether and to what extent the claims vary across countries. Let us start once again with the form of claims and more specifically on the share of protest actions as compared to all other forms (first row). Cross-national variations are striking, as witnessed by the relatively high Cramer's V. The share of protests ranges from 12 percent in France and 11 percent in Italy to as low as less-than-one percent in Sweden. These differences might suggest that this has something to do with the severity of the economic crisis as the former countries were deeply affected while the latter was only marginally or not at all so. Yet, if we look at the distributions in other countries, we see that Greece, the most deeply affected country by the economic crisis, displays a lower share of protests than both France and Italy. Spain has also a much lower share of protest actions compared to France, notwithstanding the fact that France buffered the negative effects of the crisis to a greater extent. ${ }^{4}$

\section{$\underline{\text { Table } 2 \text { about here }}$}

At first glance, what seems to be at work here is that countries with a traditional structure of political opportunities favoring mass protest, such as France, show a higher share of protests than countries that have a structure of political opportunities unfavorable to mass

\footnotetext{
${ }^{3}$ The lower share of claims that have the two types of actors as addresses, as compared to the distributions concerning subject actors and object actors, can also be explained by the fact that subjects and objects are always coded (while the addresses are not). In other words, all claims must by definition have a subject actor and an object actor, but they do not necessarily have an addressee (for example, in occasion of many claims not asking someone to act in any way).

${ }^{4}$ Based on common knowledge of the situation of our nine countries as well as on contextual data collected in the LIVEWHAT project (most notably, on indicators of economic recession), we can consider Greece, Italy, and Spain as belonging to the countries that have suffered by a deep economic crisis; Germany, Poland, Sweden and Switzerland as belonging to the countries that have not; and France and Great Britain as belonging to the countries that standing somewhere in between. This is admittedly a bit of a rough way to classify our countries, but it will give some hints as to whether the severity of the crisis has an impact on the ways in which organized actors intervene in the public domain and therefore on the structuring of the discursive field around the issue of the economic crisis.
} 
protest, such as Switzerland. That is, political opportunities seem to play a stronger role than the impact of the severity of either the economic crisis or the austerity measures implemented by governments to deal with it. More plausibly, however, an interaction among the two factors is probably at work here: the crisis, along with austerity measures as a response to it, spur protests especially in countries that have a structure of political opportunities favoring a strong protest.

A similar remark applies to the share of claims dealing with socioeconomic issues (second row). As we have already seen, these types of issues are quite prominent in public debates during the period under study. Yet they are more so in some countries than in others. For example, they take the lion's share in Great Britain, France, and Sweden, while they are much less visible especially in Spain and Switzerland. Each country has its own — nationally based-public debates and is characterized by a specific public sphere. It is not our goal here to explain or even describe in detail these national specificities. What matters for the purpose of this article is that we observe strong and significant variations across countries, suggesting that national characteristics are a crucial factor for the structuring of public debates dealing with the economic crisis.

Similar and sometimes even stronger variations can be observed when we look at economic and labor organizations as subject actors (third and fourth row), as object actors (fifth and sixth row), and as addressees (seventh and eighth row). Again without going into the details, we observe strong cross-national variations, as attested by the relatively high Cramer's V. In this regard, the share of economic organizations both as subject actors and as object actors display the strongest coefficients of all eight aspects that we are considering here, hence the deepest differences across countries.

Most importantly, once again, these cross-national variations do not seem to be linked to the impact of the crisis as they often crisscross the distinction between countries deeply 
affected by the crisis and countries that have been less so. For example, economic organizations as subject actors are most present in Sweden and least present in Greece and Spain, but at the same time they are relatively prominent in Italy; the share of labor organizations as subject actors is similarly low in Spain, Sweden, and Switzerland, while it is much higher in France and Italy; economic organizations as object actors are often mentioned in Germany, Great Britain, Italy, and Sweden, while they are much less often so in Spain; the share of labor organizations as object actors is relatively high and very similar in Greece and Italy, while it is much lower in Germany, Spain, and especially Great Britain; economic organizations as addressees are quite present in Germany, Italy and Poland, less in the other countries; finally, labor organizations as addresses have some place in France, Greece, and Italy, less in the other countries.

To stress our point further: these differences might have something to do with the crisis (we cannot exclude this with the present analysis), but they seem more plausibly linked to specific nationally-based structures of political and discursive opportunities, besides other potential factors, such as the types of industrial relations, policy networks, national traditions of mobilization and protest policing, and so forth. In fact, each aspect considered depends on a configuration of different factors at the national level. Besides the fact that variations across countries in the eight aspects of claims examined crosscut the distinction between countries deeply affected by the crisis and countries less deeply affected, a further indication that national structures "weigh" to a greater extent than the progression of the crisis is given by the coefficients of association (Cramer's V) between the eight aspects and the year (table 1), on the one hand, and those between the same eight aspects and the countries, on the other. The latter are systematically higher than the former.

The main lesson to be drawn from this simple analysis is two-fold. On the one hand, contrary to common knowledge, during the Great Recession protests have not increased 
dramatically, nor have socioeconomic issues increased in public debates. Similarly, there has been no relevant growth in the role of economic and labor organizations, neither as makers of claims nor as objects or addresses. The role of economic actors, in fact, has rather become less prominent. On the other hand, we observe strong cross-national variations in the forms, issues and actors (focusing specifically on economic and labor actors) of claims. Furthermore, such variations are not necessarily related to the extent or severity of the economic crisis, nor to the extent or severity of austerity measures. Rather, structures of political and discursive opportunities, together with other potential national-based factors specific to each country, are likely to account for much of the variation that exist in the forms, issues, and actors of claims pertaining to the economic crisis. Just as governmental responses to the economic crisis reflect the interests and power of domestic actors as well as external constraints and the nature of the economic problems at hand (Pontusson and Raess 2012), responses by collective actors are also deeply embedded in preexisting national structures and traditions.

\section{Conclusion}

In this article we have challenged a commonly hold view about the impact of the Great Recession on public debates and collective mobilizations in Europe. According to this view, the extent and severity of the economic crisis has produced major changes in the ways issues are debated in the public domain, in the place of different actors, especially economic and labor actors, and the ways they intervene. Drawing upon an original dataset made of a random sample of political claims in nine European democracies, we have proposed an alternative account inspired by the political process approach to social movements and more specifically on political opportunity theory.

Overall, our research has identified three major objectives - empirical, theoretical, and normative - that are linked to three deficits in the current discussions around the Great Recession. Firstly, we developed a context-sensitive analysis of the impact of the economic 
crisis on public debates about the crisis in terms of protest actions, socioeconomic issues, and with a particular focus on the role of economic and labor organizations. These two actors have traditionally been identified by previous research as those conflicting actors that are most likely clashing with each other owing to their affiliation to capital and labor respectively. Secondly, we stressed the role of national political opportunity structures to explain why we observe more important variations across countries than over time. According to our argument, the public domain is structured according to the specific national settings of institutions, policies, and discourse, and what we observe since the crisis is very much influenced by these national settings much more than is influenced by changing grievances (and consequent policy changes) over time. The opposition between changing grievances on the one hand and national contexts on the other is studied through a research design that tests the relevance of the former by looking at time differences, and the latter by looking at crosscountry differences. Finally, and more broadly, we have unveiled the normative underpinnings of the commonly held view that the economic crisis has fed a grievance-based conflict between capital and labor, beyond specific patterns and configurations at the national level. Our analysis of the impact that the Great Recession has taken is thus valuable to assess the extent to which the traditional interest-based model of contentious politics can still convey an effective portrait of the mobilization of economic and labor organizations. This traditional model of contentious politics fits the usual approach to politics as a zero-sum game to be fought across various cleavages dividing governors and the governed, the included and the excluded, challengers and outsiders, and - in this study — economic and labor organizations.

Far from offering a definitive answer, our findings have provided support for an alternative account along our three main objectives. Therefore, our analysis has "demystified" the common storyline about the impact of the crisis on political claims making. Empirically, we have found that protest against the crisis and austerity policies are not as widespread as the 
most updated accounts sometimes suggest (Ancelovici, Dufour, and Nez 2016), that socioeconomic issues have not become more salient in public debates during the crisis, that stronger variations emerge cross-nationally, and that the role of economic and labor organizations is far from being more central or more mutually conflictual because of the crisis.

Most crucially, and beyond the empirical analysis of the impact of the economic crisis on public debates, we have opened space for a stronger scholarly engagement with current evidences suggesting that traditional interest politics and the challengers/insiders' dynamics at the core of standard conceptualizations of contentious politics may no longer have the lion's share for explaining developments in terms of political behavior across many fields of politics. We need to work at alternative models of post-contentious politics that may be based on alternative accounts of political behavior, for example, when actors aim to produce a better collective view to the advantage of all. These new conceptualizations of non-contentious or less-than-contentious politics are also valuable to put emphasis on current processes of recomposition and articulation of contrasting positions across different political fields. NeoMarxist and neo-liberal accounts of democracy, albeit moved by opposite desires and advocating different predictions, have constructed well-established narratives of politics as the main tool by which actors compete and conflict with each other in the name of their particular advantage. Yet this dramatization of ubiquitous conflict may be overstated. And even at the time of the Great Recession, the "reason of all" may offer an alternative basis for political behavior than acting "in my own name." The Great Recession, far from being the last frontline of contentious politics, may be remembered in the future as an epochal moment marking the passage to an alternative model of post-contentious politics. 


\begin{abstract}
About the Authors
Manlio Cinalli is Research Professor at CEVIPOF (CNRS - UMR 7048), Sciences Po Paris. He has delivered teaching and research in various leading universities and institutes across Europe and the US, including Columbia University, the University of Oxford, the University of Geneva, and the École Française de Rome. Drawing upon a comparative relational approach and multi-methods research, he has published widely on citizenship, exclusion, ethnic relations, and migration. He has many large grant awards in related research fields that have contributed more than $£ 2.5 \mathrm{M}$ of research funding to host institutions.

Marco Giugni is a professor at the Department of Political Science and International Relations and Director of the Institute of Citizenship Studies (InCite) at the University of Geneva, Switzerland. His research interests include social movements, and collective action, immigration and ethnic relations, unemployment and social exclusion.
\end{abstract}


Table 1: Changes over Time in Various Aspects of Claims (2008-2014)

\begin{tabular}{|c|c|c|c|c|c|c|c|c|}
\hline & 2008 & 2009 & 2010 & 2011 & 2012 & 2013 & 2014 & $\begin{array}{r}\text { Chi2 } \\
\text { Cramer's V } \\
\text { p-value }\end{array}$ \\
\hline Share of protest actions & $\begin{array}{r}3.12 \\
(1155)\end{array}$ & $\begin{array}{r}5.26 \\
(1957)\end{array}$ & $\begin{array}{r}4.80 \\
(1187)\end{array}$ & $\begin{array}{r}6.00 \\
(1234)\end{array}$ & $\begin{array}{r}7.71 \\
1063)\end{array}$ & $\begin{array}{r}4.10 \\
(854)\end{array}$ & $\begin{array}{r}4.52 \\
(487)\end{array}$ & $\begin{array}{r}28.5531 \\
0.0600 \\
0.000\end{array}$ \\
\hline Share of socioeconomic issues & $\begin{array}{r}58.16 \\
(1219)\end{array}$ & $\begin{array}{r}60.22 \\
(2074)\end{array}$ & $\begin{array}{r}61.19 \\
(1260)\end{array}$ & $\begin{array}{r}66.31 \\
(1309)\end{array}$ & $\begin{array}{r}61.36 \\
(1131)\end{array}$ & $\begin{array}{l}62.18 \\
(928)\end{array}$ & $\begin{array}{l}61.06 \\
(511)\end{array}$ & $\begin{array}{r}20.1119 \\
0.0488 \\
0.003\end{array}$ \\
\hline Share of economic organizations as subject actors & $\begin{array}{r}34.84 \\
(1260)\end{array}$ & $\begin{array}{r}28.86 \\
(2152)\end{array}$ & $\begin{array}{r}25.54 \\
(1308)\end{array}$ & $\begin{array}{r}25.35 \\
(1353)\end{array}$ & $\begin{array}{r}23.43 \\
(1161)\end{array}$ & $\begin{array}{r}24.60 \\
(947)\end{array}$ & $\begin{array}{l}19.35 \\
(522)\end{array}$ & $\begin{array}{r}72.2441 \\
0.0911 \\
0.000\end{array}$ \\
\hline Share of labor organizations as subject actors & $\begin{array}{r}6.19 \\
(1260)\end{array}$ & $\begin{array}{r}8.64 \\
(2152)\end{array}$ & $\begin{array}{r}9.17 \\
(1308)\end{array}$ & $\begin{array}{r}7.10 \\
(1353)\end{array}$ & $\begin{array}{r}8.01 \\
(1161)\end{array}$ & $\begin{array}{r}7.39 \\
(947)\end{array}$ & $\begin{array}{r}7.66 \\
(522)\end{array}$ & $\begin{array}{r}11.2490 \\
0.0360 \\
0.081\end{array}$ \\
\hline Share of economic organizations as object actors & $\begin{array}{r}45.56 \\
(1260)\end{array}$ & $\begin{array}{r}34.90 \\
(2152)\end{array}$ & $\begin{array}{r}32.95 \\
(1308)\end{array}$ & $\begin{array}{r}30.82 \\
(1353)\end{array}$ & $\begin{array}{r}30.92 \\
(1161)\end{array}$ & $\begin{array}{r}29.36 \\
(947)\end{array}$ & $\begin{array}{r}29.12 \\
(522)\end{array}$ & $\begin{array}{r}101.9803 \\
0.1082 \\
0.000\end{array}$ \\
\hline Share of labor organizations as object actors & $\begin{array}{r}10.71 \\
(1260)\end{array}$ & $\begin{array}{r}15.61 \\
(2152)\end{array}$ & $\begin{array}{r}12.77 \\
(1308)\end{array}$ & $\begin{array}{r}11.09 \\
(1353)\end{array}$ & $\begin{array}{r}12.58 \\
(1161)\end{array}$ & $\begin{array}{l}11.30 \\
(947)\end{array}$ & $\begin{array}{l}11.49 \\
(522)\end{array}$ & $\begin{array}{r}26.5851 \\
0.0553 \\
0.000\end{array}$ \\
\hline Share of economic organizations as addressees & $\begin{array}{r}10.16 \\
(1260)\end{array}$ & $\begin{array}{r}12.45 \\
(2152)\end{array}$ & $\begin{array}{r}10.24 \\
(1308)\end{array}$ & $\begin{array}{r}9.16 \\
(1353)\end{array}$ & $\begin{array}{r}9.39 \\
(1161)\end{array}$ & $\begin{array}{r}8.34 \\
(947)\end{array}$ & $\begin{array}{r}8.05 \\
(522)\end{array}$ & $\begin{array}{r}20.6263 \\
0.0487 \\
0.002\end{array}$ \\
\hline Share of labor organizations as addressees & $\begin{array}{r}1.67 \\
(1260)\end{array}$ & $\begin{array}{r}2.65 \\
(2152)\end{array}$ & $\begin{array}{r}3.36 \\
(1308)\end{array}$ & $\begin{array}{r}1.77 \\
(1353)\end{array}$ & $\begin{array}{r}2.33 \\
(1161)\end{array}$ & $\begin{array}{r}2.75 \\
(947)\end{array}$ & $\begin{array}{r}1.72 \\
(522)\end{array}$ & $\begin{array}{r}12.4892 \\
0.0379 \\
0.052\end{array}$ \\
\hline
\end{tabular}

Note: Number of cases for calculation of percentages between parentheses. 
Table 2: Cross-National Variations in Various Aspects of Claims (2008-2014)

\begin{tabular}{|c|c|c|c|c|c|c|c|c|c|c|}
\hline & FR & GE & GR & IT & PL & ES & SE & $\mathrm{CH}$ & GB & $\begin{array}{r}\text { Chi2 } \\
\text { Cramer's V } \\
\text { p-value }\end{array}$ \\
\hline Share of protest actions & $\begin{array}{l}11.56 \\
(813)\end{array}$ & $\begin{array}{r}4.66 \\
(772)\end{array}$ & $\begin{array}{r}6.74 \\
(920)\end{array}$ & $\begin{array}{l}10.93 \\
(851)\end{array}$ & $\begin{array}{r}3.05 \\
(950)\end{array}$ & $\begin{array}{r}4.97 \\
(865)\end{array}$ & $\begin{array}{r}0.71 \\
(983)\end{array}$ & $\begin{array}{r}2.39 \\
(879)\end{array}$ & $\begin{array}{r}2.66 \\
(939)\end{array}$ & $\begin{array}{r}205.8510 \\
0.1607 \\
0.000\end{array}$ \\
\hline Share of socioeconomic issues & $\begin{array}{l}76.99 \\
(778)\end{array}$ & $\begin{array}{l}56.33 \\
(948)\end{array}$ & $\begin{array}{l}58.84 \\
(962)\end{array}$ & $\begin{array}{l}57.93 \\
(946)\end{array}$ & $\begin{array}{l}65.34 \\
(978)\end{array}$ & $\begin{array}{l}47.30 \\
(943)\end{array}$ & $\begin{array}{l}70.35 \\
(968)\end{array}$ & $\begin{array}{l}50.41 \\
(968)\end{array}$ & $\begin{array}{l}72.38 \\
(974)\end{array}$ & $\begin{array}{r}314.9799 \\
0.1929 \\
0.000\end{array}$ \\
\hline Share of economic organizations as subject actors & $\begin{array}{l}18.77 \\
(863)\end{array}$ & $\begin{array}{l}18.64 \\
(971)\end{array}$ & $\begin{array}{l}12.03 \\
(989)\end{array}$ & $\begin{array}{l}24.77 \\
(969)\end{array}$ & $\begin{array}{l}37.78 \\
(990)\end{array}$ & $\begin{array}{r}12.86 \\
(1011)\end{array}$ & $\begin{array}{l}51.42 \\
(984)\end{array}$ & $\begin{array}{l}35.45 \\
(976)\end{array}$ & $\begin{array}{l}30.15 \\
(985)\end{array}$ & $\begin{array}{r}678.7300 \\
0.2787 \\
0.000\end{array}$ \\
\hline Share of labor organizations as subject actors & $\begin{array}{l}13.56 \\
(863)\end{array}$ & $\begin{array}{r}4.12 \\
(971)\end{array}$ & $\begin{array}{r}9.50 \\
(989)\end{array}$ & $\begin{array}{l}14.55 \\
(969)\end{array}$ & $\begin{array}{r}5.15 \\
(990)\end{array}$ & $\begin{array}{r}6.03 \\
(1101)\end{array}$ & $\begin{array}{r}5.18 \\
(984)\end{array}$ & $\begin{array}{r}5.53 \\
(976)\end{array}$ & $\begin{array}{r}7.82 \\
(985)\end{array}$ & $\begin{array}{r}152.9219 \\
0.1323 \\
0.000\end{array}$ \\
\hline Share of economic organizations as object actors & $\begin{array}{l}26.65 \\
(863)\end{array}$ & $\begin{array}{r}40.78 \\
(971)\end{array}$ & $\begin{array}{l}24.47 \\
(989)\end{array}$ & $\begin{array}{l}44.07 \\
(969)\end{array}$ & $\begin{array}{l}32.22 \\
(990)\end{array}$ & $\begin{array}{r}10.48 \\
(1101)\end{array}$ & $\begin{array}{r}47.26 \\
(984)\end{array}$ & $\begin{array}{l}35.35 \\
(976)\end{array}$ & $\begin{array}{l}44.77 \\
(985)\end{array}$ & $\begin{array}{r}503.7610 \\
0.2401 \\
0.000\end{array}$ \\
\hline Share of labor organizations as object actors & $\begin{array}{l}14.14 \\
(863)\end{array}$ & $\begin{array}{r}8.14 \\
(971)\end{array}$ & $\begin{array}{r}20.32 \\
(989)\end{array}$ & $\begin{array}{l}21.36 \\
(969)\end{array}$ & $\begin{array}{l}13.03 \\
(990)\end{array}$ & $\begin{array}{r}6.73 \\
(1101)\end{array}$ & $\begin{array}{l}10.57 \\
(984)\end{array}$ & $\begin{array}{l}15.98 \\
(976)\end{array}$ & $\begin{array}{r}3.96 \\
(985)\end{array}$ & $\begin{array}{r}252.2039 \\
0.1699 \\
0.000\end{array}$ \\
\hline Share of economic organizations as addressees & $\begin{array}{r}7.88 \\
(863)\end{array}$ & $\begin{array}{l}16.89 \\
(971)\end{array}$ & $\begin{array}{r}8.49 \\
(989)\end{array}$ & $\begin{array}{l}14.55 \\
(969)\end{array}$ & $\begin{array}{l}17.07 \\
(990)\end{array}$ & $\begin{array}{r}5.54 \\
(1101)\end{array}$ & $\begin{array}{r}4.98 \\
(984)\end{array}$ & $\begin{array}{l}10.55 \\
(976)\end{array}$ & $\begin{array}{r}5.38 \\
(985)\end{array}$ & $\begin{array}{r}205.9286 \\
0.1535 \\
0.000\end{array}$ \\
\hline Share of labor organizations as addressees & $\begin{array}{r}4.29 \\
(863)\end{array}$ & $\begin{array}{r}1.85 \\
(971)\end{array}$ & $\begin{array}{r}5.76 \\
(989)\end{array}$ & $\begin{array}{r}4.02 \\
(969)\end{array}$ & $\begin{array}{r}2.22 \\
(990)\end{array}$ & $\begin{array}{r}1.58 \\
(1101)\end{array}$ & $\begin{array}{r}0.71 \\
(984)\end{array}$ & $\begin{array}{r}0.41 \\
(976)\end{array}$ & $\begin{array}{r}0.81 \\
(985)\end{array}$ & $\begin{array}{r}116.0550 \\
0.1152 \\
0.000\end{array}$ \\
\hline
\end{tabular}

Note: Number of cases for calculation of percentages between parentheses. 


\section{References}

Ancelovici, Marcos, Pascale Dufour, and Héloïse Nez. Eds. 2016. Street Politics in the Age of Austerity: From the Indignados to Occupy. Amsterdam: Amsterdam University Press.

Bermeo, Nancy, and Larry M. Bartels. Eds. 2014. Mass Politics in Tough Times: Opinion, Votes, and Protest in the Great Recession. Oxford, UK: Oxford University Press.

BinNeY, ElizABETH A., and CARROLl ESTES. 1988. "The Retreat of the State and its Transfer of Responsibility: The Intergenerational War.” International Journal of Health Services 18 (1): 83-96. Accessed on March 8, 2016. Available online at http://joh.sagepub.com/content/18/1/83.abstract

BueChleR, STEVEN M. 2004. "The Strange Career of Strain and Breakdown Theories of Collective Action." In The Blackwell Companion to Social Movements. edited by David A. Snow, Sarah A. Soule, and Hanspeter Kriesi. Malden, MA: Blackwell Publishing Ltd.

Castles, Francis G. 2004. The Future of the Welfare State. Crisis Myths and Crisis Realities. Oxford, UK: Oxford University Press.

CINALli MANLIO. 2003. "Socio-Politically Polarized Contexts, Urban Mobilization and the Environmental Movement: A Comparative Study of Two Campaigns of Protest in Northern Ireland." International Journal of Urban and Regional Research 27 (1): 158-177. Accessed on March 8, 2016. Available online at http://onlinelibrary.wiley.com/doi/10.1111/14682427.00437/abstract

2004. "Horizontal Networks vs. Vertical Networks in Multi-Organisational Alliances: A Comparative Study of the Unemployment and Asylum Issue-Fields in Britain." EurPolCom Working Papers 8: 1-25. Leeds: University of Leeds.

CinAlli, MANLIO, AND KATHARINA Fuglister 2008, "Networks and Political Contention over Unemployment: A Comparison of Britain, Germany and Switzerland." Mobilization: An International Journal 13 (3): 259-276.

CinAlli MANLIO, and MARCO GiUgni. 2013a. "New Challenges for the Welfare State: The Emergence of 'Youth Unemployment Regimes' in Europe?" International Journal of Social Welfare 22 (3): 290-299. Accessed on March 8, 2016. Available online at http://onlinelibrary.wiley.com/doi/10.1111/ijsw.12016/abstract

2013b. "Political Opportunities, Citizenship Models, and the Political Claims Making over Islam." Ethnicities 13 (X): 147-164. Accessed on March 8, 2016. Available online at etn.sagepub.com/content/13/2/147.abstract

. 2011. "Institutional Opportunities, Discursive Opportunities, and the Political Participation of Migrants." In Social Capital, Political Participation and Migration in Europe: Making Multicultural Democracy Work?, edited by L. Morales and M. Giugni, 43-62. Houndmills: Palgrave.

Clark, Andrew E., Yannis Georgellis, and Peter Sanfey. 2001. "Scarring: The Psychological Impact of Past Unemployment." Economica 68 (270): 221-241. Accessed on March 8, 2016. Available online at http://onlinelibrary.wiley.com/doi/10.1111/1468-0335.00243/abstract

Della PorTa, Donatella. 2014. Social Movements in Times of Austerity: Bringing Capitalism Back into Protest Analysis. Cambridge: Polity Press.

Della Porta, Donatella, and Alice Mattoni. Eds. 2014. Spreading Protest: Social Movements in Times of Crisis. Colchester: ECOPR Press.

Delli CARPINI, Michael, FAy LOMAX COOK, and LAWRENCE JACOBS. 2004. "Public Deliberation, Discursive Participation and Citizen Engagement: A Review of the Empirical Literature." Annual Review of Political Science 7: 315-344. Accessed on March 8, 2016. Available online at DOI: 10.1146/annurev.polisci.7.121003.091630 
DIANI, MARIO. 1995. Green Networks: A Structural Analysis of the Italian Environmental Movement. Edinburgh: Edinburgh University Press.

. 1992. "Analysing Social Movement Networks." in Studying Collective Action. Diani Mario and Eyerman R. eds. London: Sage, 107-135.

DiANI, MARIO, and Doug MACADAM. 2003. Social Movements and Networks. Relational Approaches to Collective Action. Oxford: Oxford University Press.

EISINGER, Peter K. 1973. "The Conditions of Protest Behaviour in American Cities." American Political Science Review 67 (1): 11-28. Accessed on March 8, 2016. Available online at http://www.jstor.org/stable/1958525

Engelmann, StePhen G. 2003. Imagining Interest in Political Thought: Origins of Economic Rationality. Durham: Duke University Press.

ESPING-ANDERSEN, GøSTA. 1996. "After the Golden Age? Welfare State Dilemmas in a Global Economy." In Welfare States in Transition. National Adaptations in Global Economies, edited by G. Esping-Andersen, 1-32. London: Sage.

FILlieUle, OliviER. 2005. "Requiem pour un concept. Vie et mort de la notion de structure d'opportunité politique." In La Turquie conteste: Mobilisations sociales et régime sécuritaire [Requiem for a concept. Life and Death of the notion of political opportunity structure], edited by Gilles Gorronsoro, 201-218. Paris: CNRS.

FISHKIN, JAMES. 1995. The Voice of the People. New Haven, CT: Yale University Press.

FRASER NANCY. 2015. "Legitimation Crisis? On the Political Contradictions of Financialized Capitalism." Critical Historical Studies 2 (2): 157-189. Accessed on March 8, 2016. Available online at http://www.jstor.org/stable/10.1086/683054

Gagnier, Regenia. 1997. "Neoliberalism and the Political Theory of the Market." Political Theory 25 (3): 434-454. Accessed on March 8, 2016. Available online at http://ptx.sagepub.com/content/25/3/434.extract

GAMSON, WiLLIAM, and MiCAH L. SifRY 2013. "The "Occupy Movement”, The Sociological Quarterly 54 (1): 159-230.

GiUgni, MarCo. Ed. 2010. The Contentious Politics of Unemployment in Europe: Welfare States and Political Opportunities. Houndmills, UK: Palgrave.

Giugni, Marco, and Maria T. Grasso. Eds. 2015. Austerity and Protest: Popular Contention in Times of Economic Crisis. Farnham, UK: Ashgate.

GiUgni, MARCO, and Florence PASSY. 2004. "Migrant Mobilization Between Political Institutions and Citizenship Regimes: A Comparison of France and Switzerland." European Journal of Political Research 43 (1): 51-82. Accessed on March 7, 2016. Available online at http://onlinelibrary.wiley.com/doi/10.1111/j.1475-6765.2004.00145.x/abstract

HABERMAS, JÜRGEN. 1984. The Theory of Communicative Action Vol. 1: Reason and the Rationalization of Society. Cambridge, UK: Polity Press.

HAYES, GRAEME. 2005. Environmental Protest and the State in France. Basingstoke: Palgrave.

HeCKman, James J., and GeORge J. BorJas. 1980. "Does Unemployment Cause Future Unemployment? Definitions, Questions and Answers from a Continuous Time Model of Heterogeneity and State Dependence." Economica 47 (187): 247-283. Accessed on March 8, 2016. Available online at http://www.jstor.org/stable/2553150

Hubert, Agnès. 2010. Empowering People, Driving Change: Social Innovation in the European Union, Brussels: European Commission.

JAREt, Charles. 1983. "Recent Neo-Marxist Urban Analysis." Annual Review of Sociology 9: 499525. Accessed on March 8, 2016. Available online at 
http://www.annualreviews.org/doi/abs/10.1146/annurev.so.09.080183.002435?journalCode=s $\underline{\mathrm{oc}}$

Kitschelt, Herbert. 1986. CITED ON P.4. PLEASE PROVIDE FULL DETAILS HERE IN CORRECT FORMAT. "Political Opportunity Structures and Political Protest. Anti-nuclear movements in four democracies." British Journal of Political Science 16: 57-85.

Koopmans, RUUd, and PAUl Statham. 1999. "Political Claims Analysis: Integrating Protest Event and Political Discourse Approaches." Mobilization 4 (September): 203-221. Accessed on March 8, 2016. Available online at http://mobilizationjournal.org/doi/abs/10.17813/maiq.4.2.d759337060716756

Koopmans, RuUd, Paul Statham, Marco Giugni, and Florence Passy. 2005. Contested Citizenship: Immigration and Cultural Diversity in Europe. Minneapolis: University of Minnesota Press.

KRIESI, HANSPETER. 2004. "Political Context and Opportunity." In The Blackwell Companion to Social Movements, edited by D. A. Snow, S. A. Soule, and H. Kriesi, 67-90. Oxford: Blackwell.

KRIESI, HANSPETER, and TAKIS. S. PAPPAS. Eds. 2015. European Populism in the Shadow of the Great Recession. Colchester: ECPR Press.

KRIESI, HANSPETER, RUUD KOOPMANS, JAN WILlEM DUYVENDAK, and MARCo GIUGNI. 1995. New Social Movements in Western Europe: A Comparative Analysis. Minneapolis, MS: University of Minnesota Press.

KuHNLE, SteIn. 2000. Survival of the European Welfare State. London: Routledge.

MENDELBERG, TALI. 2002. "The Deliberative Citizen: Theory and Evidence." In Research in Micropolitics: Political Decision-Making, Deliberation and Participation, edited by M. Delli Carpini, L. Huddy and R. Shapiro, 151-193. Greenwich CT: JAI Press.

MCADAM, Doug. 1986. "Recruitment to High-risk Activism: The Case of Freedom Summer." American Journal of Sociology 92 (1): 64-90. Accessed on March 8, 2016. Available online at http://www.jstor.org/stable/2779717

1996. "Political Opportunities: Conceptual Origins, Current Problems, Future Directions." In Comparing Perspectives on Social Movements: Political Opportunities, Mobilizing Structures and Cultural Framings, edited by D. McAdam, J. D. McCarthy, and M. N. Zald, 23-40. Cambridge: Cambridge University Press.

MeYer, DAvid S. 2004. "Protest and Political Opportunities." Annual Review of Sociology 30: 125145. Accessed on March 8, 2016. Available online at http://www.annualreviews.org/doi/abs/10.1146/annurev.soc.30.012703.110545?journalCode= $\underline{\text { SOC }}$

PALIER, BRUNO. 2014. "The Emerging Intergenerational Conflict." Policy Network. 1-4. Accessed on March 8, 2016. Available online at http://www.policy-network.net/pno_detail.aspx?ID=4575

PiCKeriLl, JenNy, and John KrinSKY 2012. “Why Does Occupy Matter?” Social Movement Studies 11 (3-4): 279-287.

PONTUSSON, JONAS, and DAMIEn RAESS. 2012. "How (and Why) Is This Time Different? The Politics of Economic Crisis in Western Europe and the United States." Annual Review of Political Science 15: 13-33. Accessed on March 8, 2016. Available online at http://www.annualreviews.org/doi/abs/10.1146/annurev-polisci-031710-100955

SeAring, Donald D., Frederick Solt, Pamela Johnston Connover, and IVOR Crewe. 2007. "Public Discussion and the Deliberative System: Does it Make Better Citizens?" British Journal of Political Science 37 (4): 587-618. Accessed on March 8, 2016. Available online at http://journals.cambridge.org/action/displayAbstract?fromPage $=$ online\&aid $=1340804$ 
Stiglitz, JOSEPH E. 2015. Rewriting the Rules of the American Economy: An Agenda for Growth and Shared Prosperity. New York, NY: W. W. Norton \& Company.

TARRow, SidneY. 1989. Democracy and Disorder: Protest and Politics in Italy 1965-1975. Oxford, UK: Oxford University Press.

. 2011. Power in Movement: Social Movements and Contentious Politics. Cambridge, UK: Cambride University Press.

THERBORN, GÖRAN. 1986. "Karl Marx Returning: The Welfare State and Neo-Marxist, Corporatist and Statist Theories." International Political Science Review 7 (2): 131-164. Accessed on March 8, 2016. Available online at http://ips.sagepub.com/content/7/2/131.short

TILly, CHARLES. 1978. From Mobilization to Revolution. Reading, MA: Addison-Wesley.

Tilly, Charles, and Sidney TARrow. 2007. Contentious Politics. Boulder, CO: Paradigm.

TOURAINE, A. 1971. The Post-Industrial Society. Tomorrow's Social History: Classes, Conflicts and Culture in the Programmed Society. New York, NY: Random House. 